\title{
Macrophage Migration Inhibitory Factor in Systemic Lupus Erythematosus and its Expression in Lupus Nephritis
}

\author{
Nahla Khattab ${ }^{1}$, Nihad A. El Nashar ${ }^{1}$, Nevine Badr ${ }^{2}$, \\ Hanan Fahmy ${ }^{2}$, Ragia Fahmy ${ }^{3}$, Amal Alouba ${ }^{3}$.
}

Health Radiation Research Departments ${ }^{1}$, National Centre for Radiation Research \& Technology; Physical Medicine \& Rehabilitation Department ${ }^{2}$, Faculty of Medicine Ain Shams University; Early Cancer d Dtection Unit Department ${ }^{3}$ Ain Shams University Hospitals.

\begin{abstract}
Objective: the aim of this study was to access the potential involvement of MIF in SLE, its relationship with corticosteroid dose, also, to measure serum and urinary MIF levels in SLE as well as detecting renal MIF expression in SLE GN.

Methods: Serum and urine MIF concentrations were measured by enzyme-linked immunosorbent assay in $20 \mathrm{SLE}$ female patients with lupus nephritis, World Health Organization class II, III, IV, with mean age of $35.15 \pm 10.42$ years and in 10 normal healthy, age matched, female volunteers. All patients were subjected to detailed clinical assessment and laboratory investigations. Serum and urinary MIF concentrations were measured by ELISA technique. Renal MIF expression was assessed by immunostaining of biopsy tissue. Univariate and multivariate regression analysis were used to examine the associations between serum and urine MIF concentrations, renal MIF expression, disease-related indices of SLE and corticosteroid use.

Results: A statistically significant 2.98-fold-increase was detected in mean urinary MIF (U MIF) levels in SLE patients compared to controls. While, mean Serum MIF (S MIF) showed no significant difference between cases \& control. Both S \& U MIF concentrations were positively correlated with SLICC/ACR DI but not with SLEIDAI. Corticosteroid doses showed a highly positive correlation with S MIF, serum creatinine \& SLICC/ACR DI. Also a positive correlation was found between the different histopathologic grades of renal affection \& the $U$ MIF. Immunohistochemistry staining of all normal kidney specimens showed that MIF is constitutively weakly expressed by some glomerular \& parietal epithelial cells \& by most tubular epithelial cells. In contrast, there was a significant increase in glomerular \& tubular MIF protein staining in SLE nephropathy. This increased MIF expression correlated positively with both S MIF and U MIF, SLICC/ACR DI \& the daily steroid dose

Conclusion: This study shows that serum MIF is over-expressed in SLE patients and that the urine MIF concentration is significantly increased in SLE World Health Organization class IV patients and correlates with the degree of renal injury. Thus, urine MIF levels reflect MIF expression within the kidney.
\end{abstract}

Key words: SLE, MIF, GN, renal biopsy.

\section{Introduction}

Originally described in 1966, macrophage migration inhibitory factor (MIF) was initially identified as a $12.5-\mathrm{kD}$ protein secreted by activated $\mathrm{T}$ lymphocytes capable of inhibiting random migration of macrophages, concentrating macrophages at inflammatory loci, and enhancing their ability to kill intracellular parasites and tumour cells (David,1966). Recent data indicate that other types of cells, such as macrophages, endothelial cells, and fibroblasts, can produce MIF (Steinhoff et al., 1999), and many other functions have been attributed to this molecule, such as the 
regulation of cell growth, including tumourigenesis, $\mathrm{T}$ cell activation, and angiogenesis (Lolis, 2001). MIF is constitutively expressed by $\mathrm{B}$ cells, and antagonism of MIF inhibits B cell proliferation (Chesney et al., 1999). It is also produced by $\mathrm{T}$ cells stimulated by recall antigens, mitogens, and anti-CD3 antibodies, and antagonism of MIF prevents $\mathrm{T}$ cell activation by these factors (Bacher et al., 1996). Furthermore, recent reports suggest that MIF has a critical role in inflammatory and immune responses (Metz and Bucala, 1997). In particular, MIF has been shown to induce the synthesis of proinflammatory cytokines, including tumour necrosis factor- $\alpha$ (TNF- $\alpha)$, interleukin (IL)1 and IL8 in immunocompetent cells. Moreover, it has also been verified that MIF acts as a powerful stimulator for nitric oxide production (Liew, 1994).

MIF is the only molecule described that can override the anti-inflammatory action of glucocorticoids (Calandra et al., 2000). Moreover, in animal models and in vitro, MIF has the unique ability to exert an antagonistic effect on corticosteroid suppression of immune inflammation (Santos et al., 2001). This is in contradiction with the role of MIF as a proinflammatory cytokine, but it supports the concept that physiologic levels of glucocorticoids regulate the immune inflammatory response (Amoli et al., 2002). MIF also acts in a dose dependent manner in regulating the inhibitory effects of glucocorticoids in the immune system (Donnelly and Bucala, 1997). MIF is inhibited by pharmacological concentrations of glucocorticoids. However, at low concentrations these drugs increase the synthesis of MIF (Leech et al., 2000). The hypothesis that MIF operates as a physiological counter-regulator of corticosteroids (Fingerle-Rowson et al., 2003) suggest that therapeutic antagonism of MIF may have specific steroid-sparing benefits, by increasing the immunosuppressive and anti-inflammatory properties of endogenously released glucocorticoids, thus reducing the requirement for steroid therapy in a variety of autoimmune and inflammatory conditions (Bucala, 1998).
As mentioned in several previous reports, an essential role for MIF has been established in the tuberculin delayed-type hypersensitivity reaction (Bernhagen et al., 1996), in several inflammatory skin diseases (Steinhoff et al., 1999), in wound healing process (Abe et al., 2000), in immune-mediated diseases of the central nervous system (Niino et al., 2000) and in inflammatory bowel disease (De Jong et al., 2001).

MIF potentiates lethal endotoxemia in mice and can overcome glucocorticoidmediated suppression of lethal endotoxemia (Calandra et al., 2000). A pathologic role for MIF has also been established in experimental models of arthritis (Mikulowska et al., 1997), where MIF showed a pivotal role in the pathogenesis of rheumatoid arthritis (RA) (Leech et al., 1998 and 2003) and glomerulonephritis (GN) (Lan et al., 1997 a) which has led to increasing acceptance of MIF as a key cytokine in chronic inflammatory diseases. The adminstration of specific anti-MIF monoclonal antibodies decrease arthritis disease expression (Leech et al., 2000) and inhibit the severity as well as frequency of disease (Sampey et al., 2001).

The dysregulation of MIF has recently been described in several inflammatory diseases (Meazza et al., 2002). Leech et al. (1999) demonstrated the high expression of MIF in inflamed synovial tissue from RA patients, with a unique up and down regulation, respect-ively, induced by low and high glucocorticoid concentrations. Morand et al. (2002) found a strong correlation between the synovial MIF and disease activity which corroborates existing evidence of the role of this cytokine in RA. These findings were recently confirmed by Onodera et al . (2004) who explained the migration of inflammatory cells into the synovium of rheumatoid joints to be due to induction of IL8 and IL1-beta mRNA which are up regulated by MIF. Meazza et al. (2002) reported that MIF is a relevant cytokine in the pathogenesis of juvenile idiopathic arthritis (JIA), particularly in systemiconset JIA. Also, in a recent study done by Donn et al. (2004) a functional promoter 
haplotype of MIF was found to be linked and associated with JIA. Sampey et al. (2001) showed that MIF exerts an up regulation of fibroblast-like synoviocyte phospholipase A2 and cyclooxygenase 2. Selvi et al. (2003) found a significantly higher serum concentration of MIF in patients with diffuse systemic sclerosis. Also, they found a significantly higher MIF level in the fibroblast cultures. Of particular interest in SLE is the observation that MIF is the only proinflammatory cytokine that is induced rather than suppressed by corticosteroids (Leech et al., 1999). This was confirmed by Foote et al. (2004) who found that serum MIF was overexpressed in SLE patients.

SLE is a chronic multisystem autoimmune disease with an unknown etiology, characterized by abnormalities of immuneinflammatory system function including altered $\mathrm{B}$ and $\mathrm{T}$ cell function, and by inflammation of organs including joints and kidneys (Lipsky, 2001). Corticosteroids are a mainstay of the treatment of SLE, despite their widely known side effects.

In the kidney, MIF is weakly expressed by some glomerular epithelial cells and by approximately half of the cortical tubules (Lan et al., 1998). Renal MIF mRNA and protein expression is upregulated in different types of experimental kidney disease, including crescentic antiglomerular basement membrane GN (Tesch et al., 1998). In each of these disease models, up-regulation of MIF expression is closely associated with macrophage accumulation and tissue damage. Tang et al. (1994) reported that induction of the early renal injury in this disease model is largely attributed to the early and transient neutrophil influx after the deposition of antibody and complement on the glomerular basement membrane. In contrast, the subsequent progression of renal injury is mediated by macrophages and $\mathrm{T}$ cells, which supports the concept that MIF is a key regulator of immune disease mediated by macrophages and T cells (Lan et al., 1997b). Administration of a neutralizing anti-MIF antibody inhibited macrophage and $\mathrm{T}$ cell accumulation and histologic damage, reduced proteinuria, and prevented renal dysfunction in rat crescentic antiglomerular basement membrane disease (Lan et al., 1997 b). Furthermore, administration of the anti-MIF antibody was shown to partially reverse the progressive phase of established crescentic disease in rats (Yang et al., 1998).

Analysis of renal MIF expression in human biopsy tissue revealed that renal MIF expression is upregulated in proliferative forms of GN. Renal MIF expression significantly correlates with renal dysfunction, histologic damage, and leukocytic infiltration (Lan et al., 2000). Taken together with data from functional blocking studies in the rat. These data suggest that MIF plays an important role in the pathogenesis of human proliferative GN and could be an attractive target in the treatment of progressive human GN.

Despite the accumulation of evidence for a key role for MIF in autoimmune-inflammatory diseases, MIF has not been extensively investigated in SLE. Based on the hypothesis that urinary MIF excretion may reflect the level of MIF production within the kidney, which may furthermore reflect the degree of renal injury, the aim of this study was to access the potential involvement of MIF in SLE, its relationship with corticosteroid dose, also, to measure serum and urinary MIF levels in SLE as well as detecting renal MIF expression in SLE GN.

\section{Material and Methods}

\section{Patients}

Twenty female SLE patients who fulfilled the American criteria for classification of SLE (Tan et al., 1982) with lupus nephritis WHO class II, III, IV were recruited from the outpatient clinic of Rheumatology \& Rehabilitation and nephrology departments at Ain Shams University Hospital and were enrolled in this study. Their mean age was $35.15 \pm 10.42$ years (range18-53 years).

Ten age-matched apparently healthy female volunteers, with no history of acute or chronic inflammatory disease, were enrolled from the department personnel as 
controls. Their mean age was $33.2 \pm 11.43$ years (range 19-50 years).

\section{All patients and controls were subjected to: \\ Clinical evaluation}

All patients had a detailed clinical assessment for involvement of the internal organs and were evaluated for the presence of gastrointestinal, pulmonary, cardiac, renal, or musculoskeletal affection.

Disease damage was measured using Systemic Lupus International Collaborating Clinics/American College of Rheumatology Damage Index (SLICC/ACR DI) (Gladman et al., 1996) and disease activity was assessed using the Systemic Lupus Erythematosus Disease Activity Index (SLEDAI) (Bombardier et al., 1992). Patients were classified as inactive if their SLEDAI score was less than 5, and active if their SLEDAI score was more than 10 .

Each patient was assessed for concomitant medication and corticosteroid dose was recorded as the daily dose of Prednisolone (mg/day) at the time of the study.

\section{Laboratory assessment}

\section{Routine lab works include}

1. Complete blood picture (CBC) by Coulter counter.

2. Erythrocyte sedimentation rate (ESR) by Westergren method.

3. Antinuclear antibodies (ANA).

4. Anti-dsDNA using indirect immunofluorescent antibody test.

5. Kidney function tests: including serum creatinine and proteinuria.

6. Complete urine analysis for casts, hematuria, and pyuria.

\section{Serum Samples}

All collected blood samples were limited between 9 am and $12 \mathrm{pm}$. Blood was withdrawn by venipuncture in plain tubes and left at room temperature for $1 \mathrm{hr}$ rto clot before being stored at $4^{\circ} \mathrm{C}$ for up to $4 \mathrm{hr}$. The blood then was centrifuged at $1500 \times \mathrm{g}$ for $10 \mathrm{~min}$. The serum was formed into aliquots and stored at $-80^{\circ} \mathrm{C}$. Only one freeze-thaw cycle was allowed.

\section{Urine Samples}

Sterile midstream urine samples were collected from patients and then were stored at $4^{\circ} \mathrm{C}$ for a maximum of $12 \mathrm{hr}$ before processing. A 1-ml aliquot was analyzed for urine creatinine and protienuria. The urine was centrifuged at $1500 \times \mathrm{g}$ for $10 \mathrm{~min}$ to separate debris and a protease inhibitor cocktail (Sigma, Castle Hill, New South Wales,Australia) was added; then urine was formed into aliquots and stored at $-80^{\circ} \mathrm{C}$.

\section{Serum and urine MIF Enzyme-Linked Immunosorbent Assay}

Serum and urine MIF concentrations were quantitated by enzyme-linked immunosorbent assay (ELISA) according to the manufacturer's instructions (R\&D Systems, Minneapolis, MN). In brief, ELISA plates were coated overnight with 2 $\mu \mathrm{g} / \mathrm{ml}(100 \mu \mathrm{l} /$ well $)$ mouse anti-human MIF capture antibody and incubated overnight at room temperature. Wells were washed 3 times with washing solution (10 mM PBS; $\mathrm{pH} 7.4,0.05 \%$ (wt/vol) Tween-20), blocked by $300 \mu 1$ of blocking solution (10mM PBS; $\mathrm{pH} 7.4,1 \%$ (wt/vol) bovine serum albumin (BSA), 5\% (wt/vol) sucrose, and $0.05 \%$ $\mathrm{NaN}_{3}$ in PBS) for $2 \mathrm{hr}$. Test samples (human serum, human urine, or recombinant MIF standards) diluted in Tris buffered saline-BSA $(0.1 \%$ BSA, $0.05 \%$ Tween-20, $20 \mathrm{mM}$ Tris-HCl, $150 \mathrm{mM}$ $\mathrm{NaCl}, \mathrm{pH}$ 7.3), were added in triplicate $(100 \mu \mathrm{l} /$ well $)$ and then incubated at room temperature for $2 \mathrm{hr}$. After washing with PBST, bound MIF was detected by a $2-\mathrm{hr}$ incubation with $200 \mathrm{ng} / \mathrm{ml}$ biotinylated antihuman MIF antibody diluted in $0.1 \%$ BSA, $0.05 \%$ Tween-20 in $20 \mathrm{mM}$ Tris- $\mathrm{HCl}$, and $150 \mathrm{mM} \mathrm{NaCl}, \mathrm{pH}$ 7.3. After washing, samples were incubated with $1.25 \mathrm{ng} / \mathrm{ml}$ peroxidase-conjugated streptavidin (Zymed, South San Francisco, CA) for $30 \mathrm{~min}$, washed in PBST, and then incubated for 30 min with $100 \mu 1$ /well ready-to-use 3,3',5,5;tetramethylbenzidine (Zymed) and the colorimetric reaction stopped after 20 minutes by the addition of $0.5 \mathrm{M} \mathrm{H}_{2} \mathrm{SO}_{4}$. The adsorption was measured at 450/570 $\mathrm{nm}$ with a microplate reader. MIF concentration was expressed as $\mathrm{pg} / \mathrm{ml}$ for 
serum or $\mathrm{pg} \mathrm{MIF} / \mu \mathrm{mol}$ for urine. The sensitivity limit was $18 \mathrm{pg} / \mathrm{ml}$.

MIF is stable in human urine; the ELISA measurements are constant for up to $24 \mathrm{hr}$ when stored at $4^{\circ} \mathrm{C}$ or room temperature. The MIF ELISA assay is highly reproducible, and when we analyzed samples (in triplicate) up to 12 times, the SD was $6.6 \%$ of the mean value.

\section{Renal biopsies and histopathology}

Renal biopsies were taken from 7 female SLE patients, World Health Organization class II, III and IV. In addition, five normal human kidney specimens were analyzed (from unaffected areas of nephrectomy for renal cell carcinoma).

Sections $(4 \mu \mathrm{m})$ of formalin-fixed, paraffin-embedded biopsy tissue were stained with hematoxylin and eosin. The percentage of glomeruli exhibiting crescent formation was scored in 10-30 glomerular cross sections (gcs) per biopsy. Glomerular hypercellularity was assessed as follows: 0 $=$ normal (less than 60 cells $/ g c s) ; 1=$ mild $(60-90$ cells $/ \mathrm{gcs}) ; 2=$ moderate $(90-120$ cells/gcs); and $3=$ severe (more than 120 cells/gcs).

\section{Antibodies}

Mouse monoclonal antibodies $(\mathrm{MoAb})$ used for immunostaining were as follows: IIID9, mouse MoAb raised against recombinant mouse MIF that cross-reacts with human MIF; UCHL1, mouse antiCD45RO, which recognizes mature, activated $\mathrm{T}$ cells and a subset of resting $\mathrm{T}$ cells (Smith et al.,1986); and KP1, mouse anti-CD68, which labels most monocytes and macrophages (Pulford et al., 1989). Peroxidase and alkaline phosphataseconjugated goat anti-mouse IgG, mouse peroxidase-conjugated anti-peroxidase complexes, and mouse alkaline phosphataseconjugated anti-alkaline phosphatase complexes were purchased from Dakopatts (Glostrup, Denmark).

\section{MIF expression using Immunohistoche- mistry Staining:}

Two-color immunohistochemistry

staining was performed as described previously (Lan et al., 2000). Paraffin sections $(4 \mu \mathrm{m})$ were treated with 10-min microwave oven heating in $10 \mathrm{mM}$ sodium citrate, $\mathrm{pH} 6.0$, at $2450 \mathrm{MHz}$ and $800 \mathrm{~W}$. Sections then were preincubated with $10 \%$ fetal calf serum and 10\% normal goat serum in PBS for $20 \mathrm{~min}$, drained, and incubated with KP1 or UCHL1 MoAb overnight at $4^{\circ} \mathrm{C}$. Sections then were washed in PBS, endogenous peroxidase inactivated in $0.3 \% \quad \mathrm{H}_{2} \mathrm{O}_{2}$ in methanol, incubated with peroxidase-conjugated goat anti-mouse IgG, washed in PBS, incubated with mouse peroxidase-conjugated antiperoxidase complexes, and developed with 3,3-diaminobenzidine to produce a brown colour. Slides then underwent a second microwave treatment to denature the bound $\mathrm{Ig}$ and prevent antibody cross reactivity (Lan et al., 1995). Sections then were preincubated with $10 \%$ fetal calf serum and $10 \%$ normal goat serum in PBS for $20 \mathrm{~min}$, followed by $10 \%$ bovine serum albumin in PBS for $20 \mathrm{~min}$, washed, and labeled with the anti-MIF MoAb overnight at $4^{\circ} \mathrm{C}$. After washing in PBS, sections then were incubated sequentially with alkaline phosphatase-conjugated goat anti-mouse IgG and mouse alkaline phosphataseconjugated anti-alkaline phosphatase complexes and then developed with Fast Blue BB Salt (Ajax Chemicals, Melbourne, Australia). Sections were counterstained with periodic acid-Schiff (minus hematoxylin) and mounted in an aqueous medium.

\section{Quantitation of Immunohistochemistry Staining}

The number of immunostained cells were counted under high-power microscope fields (x400) in all glomeruli (10-30) for each biopsy and expressed as cell per gcs. The number of KP1-positive and UCHL1positive interstitial cells was counted in high-power fields of the cortex with a 0.02 $\mathrm{mm}^{2}$ graticule fitted in the eyepiece of the microscope for the entire biopsy and expressed as cells per square millimeter. No adjustment of the interstitial cell count was made for tubules or the luminal space. Cortical tubular MIF staining was scored from the entire cortex of the biopsy and 
expressed as the percentage of positive tubules. Data are expressed as means \pm SD.

\section{Statistical Analysis}

Results are expressed as mean \pm SD. Comparisons were made by student t-test for independent groups and by paired samples t-test for dependent groups. Correlations between variables were tested by Pearson correlation coefficient, $\mathrm{p}<0.05$ was considered statistically significant.

\section{Results}

Twenty SLE female patients, with mean age of $35.15 \pm 10.42$ years (range18-53 years), mean disease duration of $3.68 \pm 2.45$ years (range 0.5- 10 years) were enrolled in this study. The results of lab works showed that 15 patients had positive ANA (75\%), 17 patients had positive anti-dsDNA (85 $\%)$. The mean serum creatinine levels of patients was $1.8 \pm 1.69 \mathrm{mg} / \mathrm{dl}$. Patients showed a mean SLEDAI score of 5.55 \pm 2.54 and a mean SLICC/ACR DI of 3.15 \pm 2.01 . The mean steroid dose for patients was $25.13 \pm 19.59 \mathrm{mg} / \mathrm{day}$. Four renal biopsies taken from patients showed SLE WHO class IV, two biopsies showed class III, while one showed class II. Clinical and laboratory data are shown in table 1.

Our Biochemical results showed that there was a statistically significant 2.98fold increase in mean urinary MIF (U MIF) levels in SLE patients $(621.35 \pm 330.65 \mathrm{pg}$ $\mathrm{MIF} / \mu \mathrm{mol}$, range 148 to 1290 ) than in controls (208.5 \pm 102.53 , range 53 to $420 \mathrm{pg}$ $\mathrm{MIF} / \mu \mathrm{mol}) \mathrm{P}<0.05$. While, mean serum MIF (S MIF) showed no statistical significant difference between cases (949.4 \pm 693.48 , range 210 to $2005 \mathrm{pg} / \mathrm{ml}$ ) and control $(599.9 \pm 460.08$, range 105 to $1760 \mathrm{pg} / \mathrm{ml}) \mathrm{P}>0.05$

Also, there was a positive correlation between disease damage index SLICC/ACR DI and both S MIF ( $\mathrm{r}=0.82$, $\mathrm{P}<0.05)$ (fig $1 \mathrm{~A})$, and $\mathrm{U}$ MIF $(\mathrm{r}=0.92$, $\mathrm{P}<0.05$ ) (fig $1 \mathrm{~B}$ ). However, disease activity (SLEIDAI) scores did not show any correlation with either $\mathrm{S}$ MIF $(\mathrm{r}=-0.18$ $\mathrm{P}=0.44)$, or with $\mathrm{U} \mathrm{MIF}(\mathrm{r}=-0.25 \mathrm{P}=0.29)$.

A statistically significant higher mean level of serum creatinine was found in SLE patients $(1.8 \pm 1.69 \mathrm{mg} / \mathrm{dl})$ compared to control $(0.5 \pm 0.23 \mathrm{mg} / \mathrm{dl}) \mathrm{P}<0.05$. There was also a positive correlation between $\mathrm{S}$ MIF and $\mathrm{S}$ creatinine $\mathrm{P}<0.05$ (Fig 2)

Corticosteroid doses showed a mean of $25.13 \pm 19.59 \mathrm{mg} /$ day in SLE patients and showed a highly positive correlation with both S MIF ( $\mathrm{r}=0.95, \mathrm{P}<0.0001)$ and serum creatinine ( $r=0.9, P<0.0001$ (Fig 3). There was also a highly positive correlation between steroid dose and SLICC/ACR DI $(\mathrm{r}=0.77, \mathrm{P}<0.0001)$.

Our histopathologic results of the 7 renal SLE specimens indicated that four renal biopsies showed SLE WHO class IV, two biopsies showed class III, while one showed class II glomerulonephritis (GN). Not only did the mean urinary MIF (U MIF) levels in SLE patients showed a statistically significant 2.98 -fold increase (621.35 $330.65 \mathrm{pg} \mathrm{MIF} / \mu \mathrm{mol})$ than in controls $(208.5 \pm 102.53 \mathrm{pg} \mathrm{MIF} / \mu \mathrm{mol})$, but also a positive correlation was found between the different grades of renal affection and the $\mathrm{U}$ MIF $(\mathrm{r}=0.82, \mathrm{P}<0.05$. figure 4$)$.

Also, three of the 7 biopsies examined showed severe glomerular hypercellularity (>120 cells/gcs), 3 showed moderate hypercellularity (90-120 cells/gcs), while one showed mild hypercellularity (60-90 cells/gcs). The detected glomerular hypercellularity highly positively correlated with both S MIF ( $\mathrm{r}=0.85, \mathrm{P}=0.02$; Fig $5 \mathrm{~A}$ ) and $\mathrm{U}$ MIF ( $\mathrm{r}=0.89, \mathrm{P}=0.007$; Fig 5B).

Immunohistochemistry staining of all normal kidney specimens showed that MIF is constitutively weakly expressed by some glomerular and parietal epithelial cells and by most tubular epithelial cells. In contrast, there was a significant increase in glomerular and tubular MIF protein staining in SLE nephropathy (Fig 6). This increased MIF expression correlated positively with both S MIF ( $\mathrm{r}=0.89, \mathrm{P}=0.007)$ (Fig 7A), and $\mathrm{U}$ MIF ( $\mathrm{r}=0.82, \mathrm{P}=0.02$ ) (Fig 7B). MIF expression also correlated positively with SLICC/ACR DI $(\mathrm{r}=0.89, \mathrm{P}=0.008)$ (Fig $8 \mathrm{~A})$, and the daily steroid dose $(\mathrm{r}=0.82$, $\mathrm{P}=0.02$ ) (Fig 8B), but not with SLEDAI ( $\mathrm{r}=$ $-0.46, \quad \mathrm{P}=0.3$ ). Again, studying the correlation between the hypercellularity and either the SLICC/ACR or the steroid dose, 
we found a positive correlation between hypercellularity and both variables $(r=0.95$,
0.87; $\mathrm{P}=0.001$ and 0.01 , respectively) (Fig 9 $\mathrm{A}$ and $\mathrm{B})$.

Table (1): Showing the clinical and laboratory data of both groups

\begin{tabular}{|c|c|c|c|c|c|c|}
\hline & \multicolumn{2}{|c|}{ SLE cases $(\mathrm{N}=20)$} & \multicolumn{2}{|c|}{ Controls $(\mathrm{N}=10)$} & \multirow[t]{2}{*}{$t$} & \multirow[t]{2}{*}{ S 2-tail) } \\
\hline & Mean & SD & Mean & SD & & \\
\hline Age & 35.15 & 10.42 & 33.20 & 11.43 & -.468 & 0.643 \\
\hline Disease duration & 3.68 & 2.45 & & & & \\
\hline $\mathrm{S}$ creatinine & 1.8 & 1.69 & 0.5 & 0.23 & -2.405 & 0.023 \\
\hline SLEDAI & 5.55 & 2.54 & & & & \\
\hline SLICC/ACR DI & 3.15 & 2.01 & & & & \\
\hline S MIF & 949.4 & 693.48 & 599.9 & 460.08 & -1.437 & 0.162 \\
\hline U MIF & 621.35 & 330.65 & 208.5 & 102.53 & -3.827 & 0.001 \\
\hline Steroid dose & 25.13 & 19.59 & & & & \\
\hline G hypercellularity & 112.14 & 19.8 & & & & \\
\hline GN grade & 3.43 & 0.79 & & & & \\
\hline MIF expression & 2.43 & 0.79 & & & & \\
\hline
\end{tabular}

Figure (1): Correlation between disease damage index (SLICC/ACR DI) and both A)serum and B)urinary MIF

A) disease damage index (SLICC/ACR DI) with S MIF

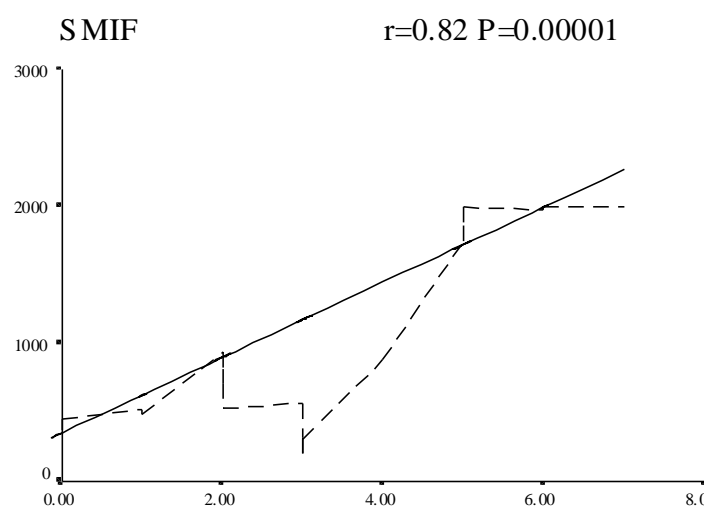

SLICC/DI
B) disease damage index (SLICC/ACR DI) with U MIF

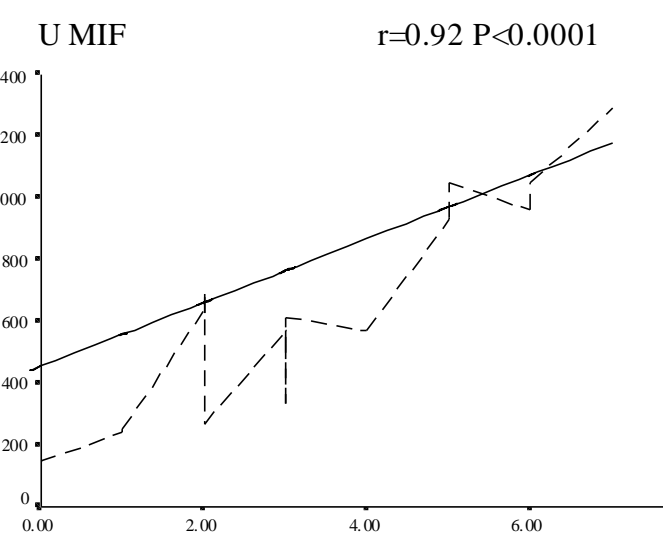

SLICC/DI 
Figure (2): Showing the correlation between S MIF and S creatinine

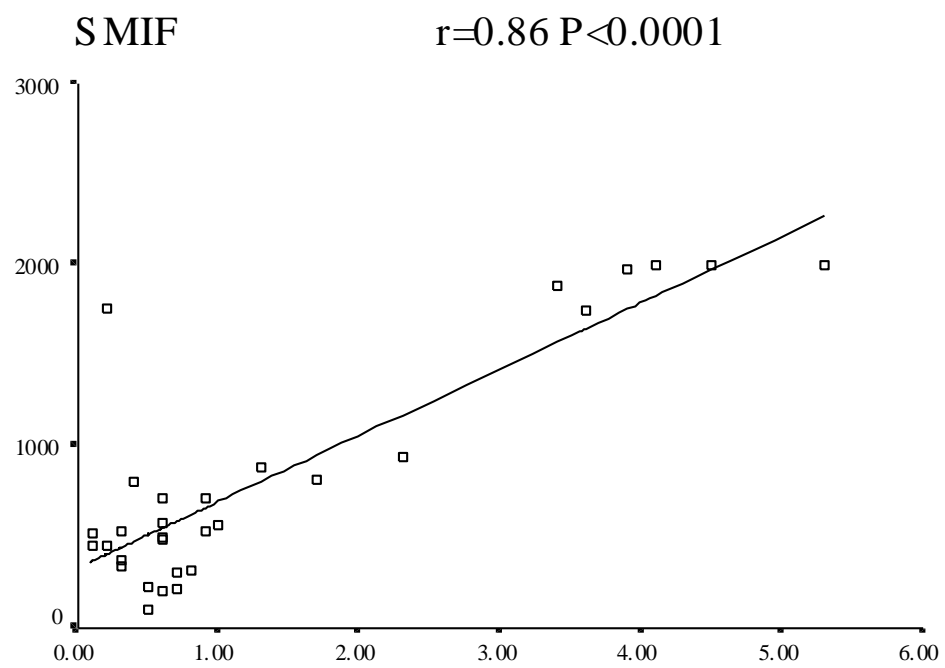

S creatinine

Figure (3): Correlation between steroid dose and A) S MIF and B) serum creatinine

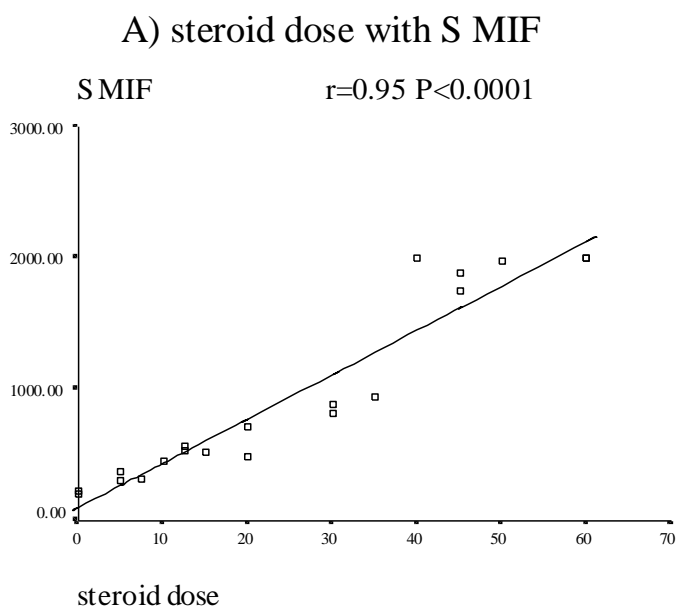

B) steroid dose with serum creatinine

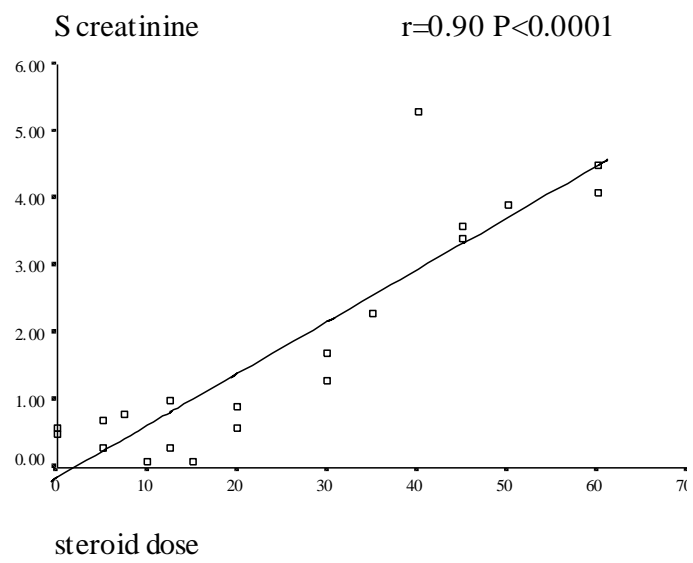


Figure (4): Correlation between different grades of renal affection and U MIF

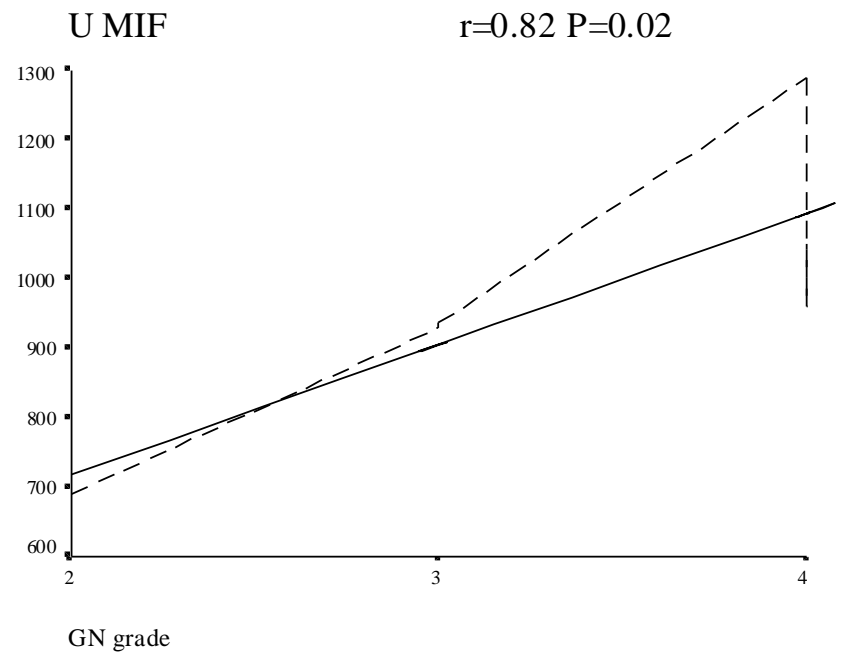

Figure (5): Correlation between glomerular hypercellularity in renal specimens and A) $S$ MIF and B) U MIF

A) Glomerular hypercellularity with S MIF

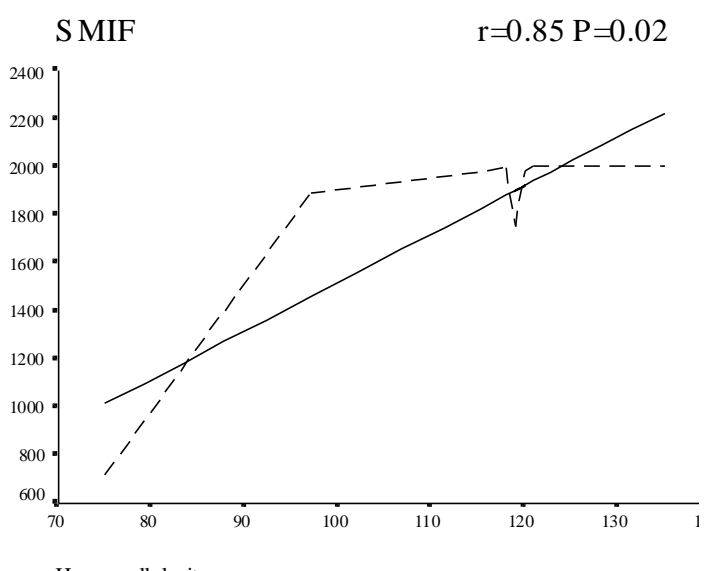

Hype rcellularity
B) Glomerular hypercellularity with U MIF

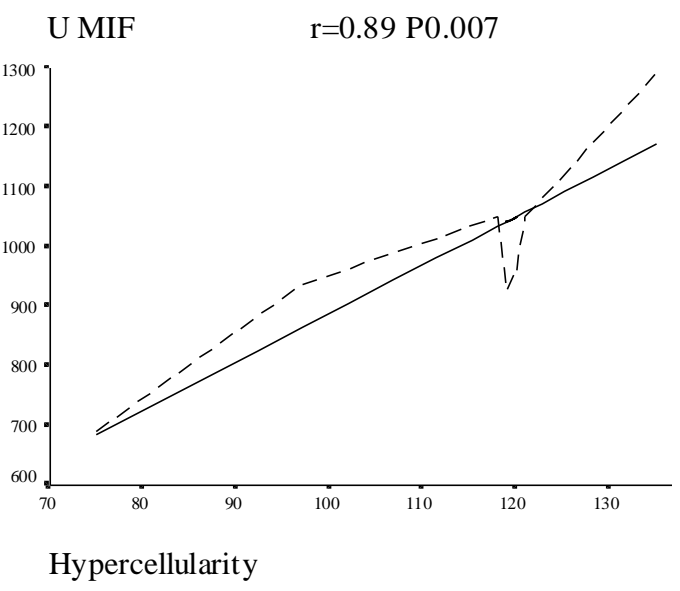


Figure (6): Double immunohistochemistry staining of MIF (blue) and leukocytic infiltration (brown) in SLE nephritis showing marked constitutive MIF expression by some glomerular cells and approximately half of the cortical tubules in association with prominent focal accumulation of macrophages.
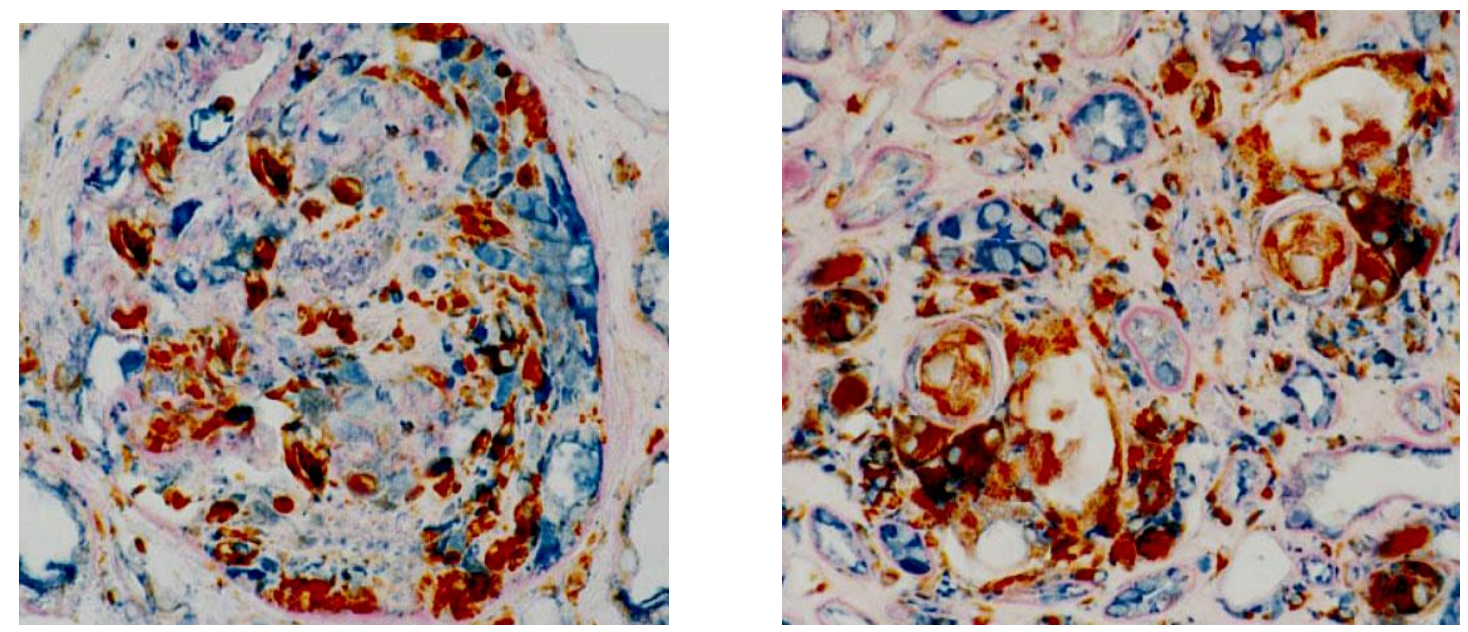

Figure (7): Correlation between MIF expression in renal specimens and A) S MIF and B) U MIF

A) MIF expression with S MIF

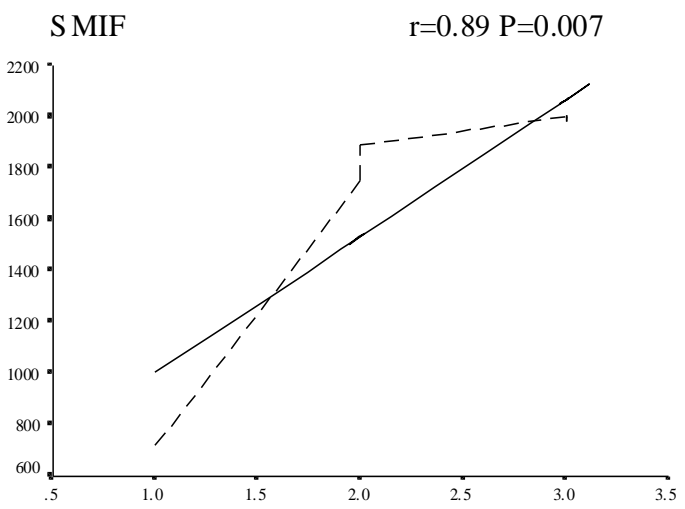

MIF expression
B) MIF expression with U MIF

$$
\text { U MIF } \quad \mathrm{r}=0.82 \mathrm{P}=0.02
$$

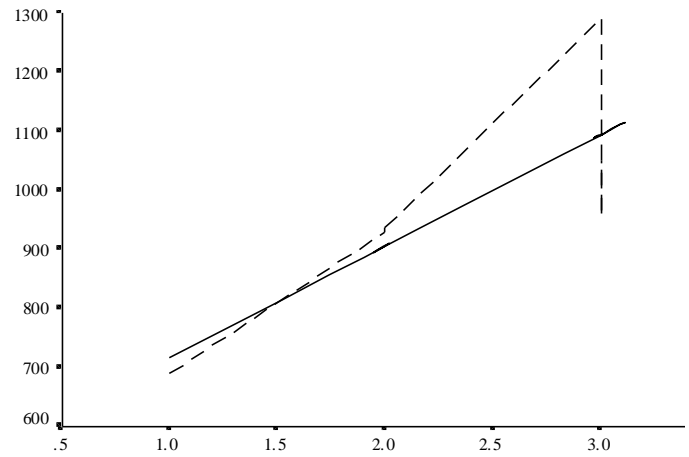

MIF expression 
Figure (8): Correlation between MIF expression in renal specimens and A) SLICC/ACR DI and B) steroid dose

A) MIF expression with SLICC/ACR DI

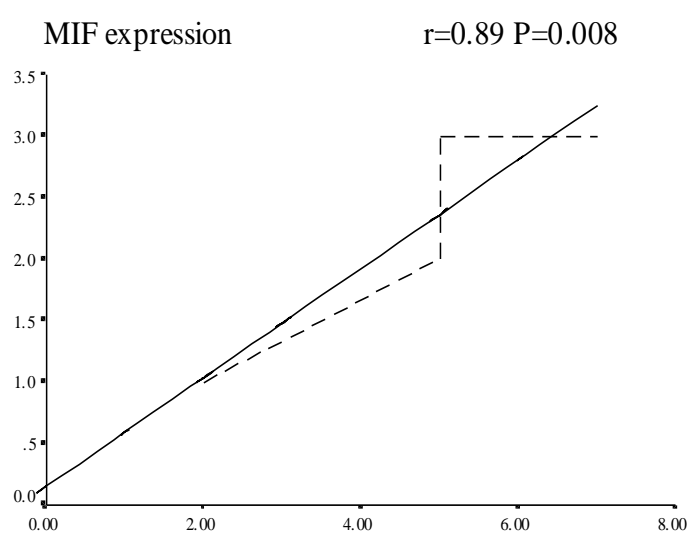

SLICC/DI
B) MIF expression with steroid dose

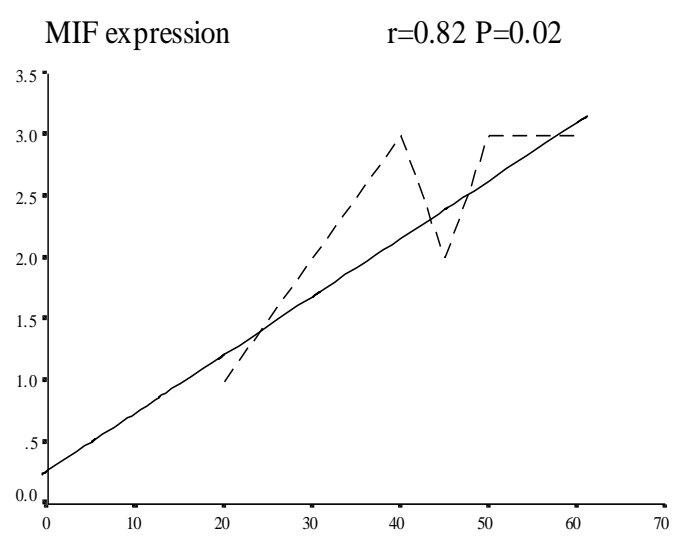

Steroid dose

Figure (9): Correlation between glomerular hypercellularity in renal specimens and A) SLICC/ACR DI and B) steroid dose

A) Glomerular hypercellularity with B) Glomerular hypercellularity with steroid SLICC/ACR DI dose

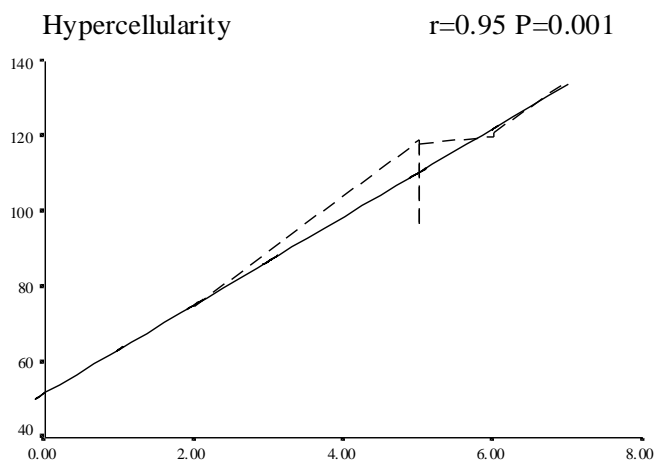

SLICC/DI

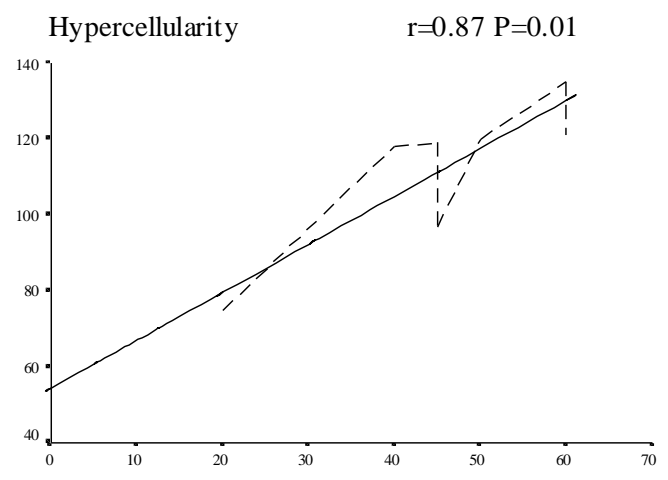

Steroid dose

\section{Discussion}

Although the etiology of SLE remains unknown, it is clear that patients with SLE have a wide variety of immunoregulatory abnormalities leading to autoimmune mediated organ injury. Immmunoregulatory abnormalities observed in SLE include hyperresponsive $\mathrm{B}$ cells and abnormal antibody production, as well as abnormal $\mathrm{T}$ cell responses (Lipsky, 2001). MIF has

been identified as a mediator of activation of B and T cells (Chesney et al., 1999), as well as of synovial cells, endothelium, and glomerular cells (Sampey et al., 2001). In addition, MIF is expressed in inflammatory lesions in organs targeted by SLE including joints, kidney, bowel, skin, and brain. It is increasingly accepted that MIF contributes to the pathogenesis of autoimmune inflam- 
matory diseases including RA, immune glomerulonephritis, inflammatory bowel disease, psoriasis, and multiple sclerosis (Leech et al., 2000).

The range of effects of MIF in the immune system, and its expression in target organs of SLE, led us to the hypothesis that MIF is involved in the pathogenesis of inflammatory organ injury in SLE. Our results show that patients with SLE were more likely to have elevated serum MIF concentrations than controls. This contradicts the report done by Mizue et al (2000), in which a fourfold increase in serum MIF levels was described in patients with SLE. Unfortunately, this report gave no patient details, so that the severity and systemic symptoms in these SLE cases are unknown, thus making it difficult to compare with the patient group in this study. One possible explanation for the apparent discrepancy is that increased serum MIF reflects systemic symptoms because the SLE patient group in this study had primarily renal involvement without systemic disease. Further studies are needed to clarify this issue.

Disease related damage, as measured using the SLICC/ACR DI was greater in patients with higher serum MIF concentration. This association was independent of current corticosteroid dose. Similarly, patients with high SLICC/ACR DI scores were more likely to have abnormally elevated values of serum MIF. These data suggest that serum MIF is associated with disease severity in SLE. Possible explanations of this could include MIF gene polymorphisms, such as those recently described in patients with inflammatory arthritis (Baugh et al., 2002).

We were unable to find a relationship between serum MIF and disease activity score, as our study included patients with very low disease activity scores.

Our analysis of the relationship between serum MIF and corticosteroid use in SLE patients showed that corticosteroid use was positively associated with serum MIF, particularly at higher doses, which confirms the results reported by Foote et al (2004).
This study demonstrates that MIF is readily detected in the urine of normal, healthy volunteers. Urinary MIF was increased about 2.98 fold over normal levels in the SLE patients. The urine MIF concentration correlated with the degree of renal dysfunction, histologic damage, leukocytic infiltration, and renal MIF expression.

The increase in urinary MIF concentration seen in SLE patients is probably the result of increased local production and secretion of MIF within the injured kidney. This postulate is supported by two findings. There was a significant correlation between renal MIF expression assessed by immunohistochemistry staining and the urine MIF concentration. MIF expression was increased in the glomerulus (resident and infiltrating mononuclear cells) and in tubular epithelial cells, both potential sites of MIF secretion into the urinary space. In support of this concept, Rice et al. (1999) have reported that interferon gamma, a cytokine implicated in the development of kidney disease, can induce rapid secretion of MIF by mesangial cells and tubular epithelial cells in vitro and suggested in a recent study done in 2003 that this may be an important mechanism leading to inflammatory cell accumulation and activation during kidney disease. The increase in MIF immunostaining in the biopsy tissues is consistent with the previous study done by Lan et al. (2000) in which the upregulation of MIF mRNA and protein expression was described in a different cohort of GN patients.

This study has shown that in an individual patient, the urine and renal MIF correlated with the severity and activity of GN (glomerular hypercellularity and crescent formation, the degree of interstitial damage, mononuclear cell infiltrate, and loss of renal function). Therefore, the urine MIF concentration may be useful in monitoring patients for the degree of disease activity. However, Brown et al. (2002) found that urine MIF concentration is not useful in identifying a specific type of GN in an individual patient, although a high urine MIF level does suggest a more severe proliferative form of GN. Further studies 
are needed to assess how urine MIF excretion changes with time in individual patients. In particular, it is important to determine whether urine MIF could be an early indicator of a flare of disease activity.

In summary, this study found that the serum concentration of MIF is more likely to be elevated above the normal range in SLE, as in other inflammatory diseases. Also, urine MIF concentration is significantly increased in SLE World Health Organization class IV and correlated with the degree of renal dysfunction, histological damage, and leukocytic infiltration. Prospective studies of the association between MIF and disease activity using validated indices of disease activity, and including patients with active disease, are required.

\section{References}

1. Abe R, Shimizu T, Ohkawara A and Nishihira J (2000): Enhancement of macrophage migration inhibitory factor (MIF) expression in injured epidermis and cultured fibroblasts. Biochim. Biophys. Acta 1500:1-9.

2. Amoli MM, Donn RP, Thomson W, Hajeer AH, Garcia-Porrua C, Lueiro M, Ollier WE and Gonzalez-Gay MA (2002): Macrophage migration inhibitory factor gene polymorphism is associated with sarcoidosis in biopsy proven Erythema Nodosum. J. Rheumatol.,29:1671-3.

3. Bacher M, Metz CN, Calandra T, Mayer $\mathrm{K}$, Chesney J, Lohoff M, Gemsa D, Donnelly $T$ and Bucala $R$ (1996): An essential regulatory role for macrophage migration inhibitory factor in T-cell activation. Proc Natl Acad Sci USA 93: 7849-54.

4. Baugh JA, Chitnis S and Donnelly SC (2002): A functional promoter polymorphism in the macrophage migration inhibitory factor (MIF) gene associated with disease severity in rheumatoid arthritis. Genes Immun 3:170-6.

5. Bernhagen $\mathbf{J}$, Bacher $\mathbf{M}$, Calandra $\mathbf{T}$, Metz CN, Doty SB, Donnelly $T$ and Bucala R (1996): An essential role for macrophage migration inhibitory factor in the tuberculin delayed-type hypersensitivity reaction. J. Exp. Med., 183: 277-82.
6. Bombardier C, Gladman D, Urowitz MB, et al (1992): Derivation of the SLEDAI. A disease activity index for lupus patients. The committee on Prognosis Studies in SLE. Arthritis Rheum; 35:630.

7. Brown FG, Nikolic-Paterson DJ, Hill PA, Isbel NM, Dowling J, Metz CM and Atkins RC (2002):

Urine Macrophage Migration Inhibitory Factor Reflects the Severity of Renal Injury in Human Glomerulonephritis. J Am Soc Nephrol 13:S7-S13.

8. Bucala R (1998): Neuroimmunomo-dulation by macrophage migration inhibitory factor (MIF).Ann N Y Acad Sci 840:74-82.

9. Calandra T, Echtenacher B, Roy DL, Pugin J, Metz CN, Hultner L, Heumann D, Mannel D, Bucala $R$ and Glauser MP (2000): Protection from septic shock by neutralization of macrophage migration inhibitory factor. Nat Med 6: 164-70.

10. Chesney J, Metz C, Bacher M, Peng T, Meinhardt A and Bucala R (1999): An essential role for macrophage migration inhibitory factor (MIF) in angiogenesis and the growth of a murine lymphoma. Mol Med 5: 181-91.

11. David JR (1966): Delayed hypersensitivity in vitro: Its mediation by cell substances formed by lymphoid cell-antigen interaction. Proc Natl Acad Sci USA 56: 72-7.

12. De Jong YP, Abadia-Molina AC, Satoskar AR, Clarke K, Rietdijk ST, Faubion WA, Mizoguchi E and Metz CN (2001): Development of chronic colitis is dependent on the cytokine MIF. Nat Immunol 2: 1061-6.

13. Donn R, Alourfi Z, Zeggini E, Lamb R, Jury F, Lunt M, Meazza C, DeBenedetti F, Thomson W and Ray D (2004): A functional promoter haplotype of macrophage migration inhibitory factor is linked and associated with juevenile idiopathic arthritis. Arthritis Rheum 50(5):1604-10.

14. Donnelly SC and Bucala R (1997): Macrophage migration inhibitory factor: a regulator of glucocorticoid activity with a critical role in inflammatory disease. Mol Med. Today., 3:502-7.

15. Fingerle-Rowson G, Koch P, Bikoff R, Lin X, Metz CN, Dhabhar FS, Meinhardt $A$ and Bucala $R$ (2003): Regulation of macrophage migration inhibitory factor expression by 
glucocorticoids in vivo. Am. J. Pathol., 162:47-56

16. Foote A, Briganti EM, Kipen Y, Santos I, Leech $M$ and Morand EF (2004): Macrophage migration inhibitory factor in Systemic lupus Erythematosus. J Rheumatol., 31:268-73.

17. Gladman G, Ginzler $\mathbf{E}$ and Goldsmith $\mathbf{C}$ (1996): The development and initial validation of the Systemic Lupus International Collaborating Clinics/American college of Rheumatology damage index for Systemic Lupus Erythematosus. Arthritis Rheum., 39:363-9.

18. Lan HY, Mu W, Nikolic Paterson DJ and Atkins RC (1995): A novel, simple, reliable, and sensitive method for multiple immunoenzyme staining: Use of microwave oven heating to block antibody crossreactivity and retrieve antigens. J Histochem. Cytochem., 43: 97-102.

19. Lan HY, Yang N, Metz C, Mu W, Song Q, Nikolic-Paterson DJ, Bacher M, Bucala R and Atkins RC (1997a): TNFalpha up-regulates renal MIF expression in rat crescentic glomerulonephritis. Mol. Med., 3: 136-44.

20. Lan HY, Bacher M, Yang N, Mu W, Nikolic-Paterson DJ, Metz C, Meinhardt A, Bucala R and Atkins RC (1997b): The pathogenic role of macrophage migration inhibitory factor in immunologically induced kidney disease in the rat. J. Exp Med., 185: 1455-65.

21. Lan HY, Yang N, Brown FG, Isbel NM, Nikolic-Paterson DJ, Mu W, Metz CN, Bacher M, Atkins RC and Bucala $R$ (1998): Macrophage migration inhibitory factor expression in human renal allograft rejection. Transplantation., 66: 1465-71.

22. Lan HY, Niasheng Y, Nikolic-Paterson DJ, Xue QY, Mu W, Isbel N, Metz C, Bucala $R$ and Atkins RC (2000): Expression of macrophage migration inhibitory factor in human glomerulonephritis. Kidney Int., 57: 499-509.

23. Leech M, Metz C, Santos L, Peng T, Holdsworth SR, Bucala $R$ and Morand EF (1998): Involvement of macrophage migration inhibitory factor in the evolution of rat adjuvant arthritis. Arthritis Rheum., 41: 910-7.

24. Leech M, Metz CN and Smith M (1999): Macrophage migration inhibitory factor (MIF) in rheumatoid arthritis: Evidence for pro-inflammatory function and regulation by glucocorticoids. Arthritis Rheum., 42: 1601-8.
25. Leech M, Santos LL, Metz CN, Holdsworth SR, Bucala $R$ and Morand EF (2000): Control of macrophage migration inhibitory factor (MIF) by endogenous glucocorticoids in rat adjuvant arthritis. Arthritis Rheum., 43:827-33.

26. Leech M, Lacey D, Xue JR, Santos L, Hutchinson P, Wolvetang E, David JR, Bucala $R$ and Morand EF (2003): Regulation of P53 by macrophage migration inhibitory factor in inflammatory arthritis. Arthritis Rheum., 48(7): 1881-9.

27. Liang MH, Socher SA, Larson MG and Schur PH (1989): Reliability and validity of six systems for the clinical assessment of disease activity in Systemic Lupus Erythematosus. Arthritis Rheum., 32: 1107-18.

28. Liew F (1994): Regulation of nitric-oxide synthesis in infectious and autoimmune diseases. Immunol Lett., 43:95-8.

29. Lipsky P (2001): Systemic Lupus Erythematosus: an autoimmune disease of B cell hyperactivity. Nat Immun 2:764-6.

30. Lolis E (2001): Glucocorticoid counter regulation: macrophage migration inhibitory factor as a target for drug discovery. Curr Opin Pharmacol., 1:662-8.

31. Meazza C, Travaglino P, Pignatti P, Magni-Manzoni S, Ravelli A and Martini A (2002): Macrophage migration inhibitory factor in patients with juvenile idiopathic arthritis. Arthritis Rheum., 46:232-7.

32. Metz CN and Bucala R (1997): Role of macrophage migration inhibitory factor in the regulation of the immune response. Adv Immunol., 66: 197-223.

33. Mikulowska A, Metz CN, Bucala $R$ and Holmdahl R (1997): Macrophage migration inhibitory factor is involved in the pathogenesis of collagen type II-induced arthritis in mice. J. Immunol., 158: 5514-7.

34. Mizue Y, Nishihira J, Miyazaki $T$, Fujiwara S, Chida M, Nakamura K, Kikuchi $K$ and Mukai M (2000): Quantitation of macrophage migration inhibitory factor (MIF) using the one-step sandwich enzyme immunosorbent assay: Elevated serum MIF concentrations in patients with autoimmune diseases and identification of MIF in erythrocytes. Int J. Mol. Med., 5: 397-403.

35. Morand EF, Leech M, Weedon H, Metz C, Bucala $R$ and Smith MD (2002): Macrophage migration inhibitory factor in Rheumatoid Arthritis: Clinical correlations. Rheumatology., 41:558-62.

36. Niino M, Ogata A, Kikuchi S, Tashiro K and Nishihira J (2000): Macrophage 
migration inhibitory factor in the cerebrospinal fluid of patients with conventional and optic-spinal forms of multiple sclerosis and neuro-Behcet disease. J. Neurol. Sci 1;179(S1-2):127-31.

37. Onodera S, Nishihira J, Koyama Y, Majima T, Aoki Y, Ichiyama H, Ishibashi $T$ and Minami A (2004): Macrophage migration inhibitory factor upregulates the expression of interleukin-8 messenger RNA in synovial fibroblasts of rheumatoid arthritis patients: common transcriptional regulatory mechanism between interleukin-8 and interleukin-1 beta. Arthritis .Rheum., 50 (5):1437-47.

38. Pulford KA, Rigney EM, Micklem KJ, Jones M, Stross WP, Gatter KC and Mason DY (1989): KP1: A new monoclonal antibody that detects a monocyte/macrophage associated antigen in routinely processed tissue sections. J Clin Pathol., 42: 414-21.

39. Rice EK, Nikolic-Paterson DJ, Metz C, Bucala R, Atkins RC and Tesch GH (1999): IFN- $\gamma$ induces rapid release of macrophage migration inhibitory factor in renal parenchymal cells [Abstract]. J Am Soc Nephrol., 10: 460A.

40. Rice EK, Nikolic-Paterson DJ, Hill PA, Metz CN, Bucala R, Atkins RC and Tesch GH (2003): Interferon- $\gamma$ induces macrophage migration inhibitory factor synthesis and secretion by tubular epithelial cells. Nephrology., 8:156.

41. Sampey AV, Hall PH, Mitchell RA, Metz CN and Morand EF (2001): Regulation of synoviocyte phospholipaseA2 and cyclooxygenase 2 by macrophage migration inhibitory factor. Arthritis Rheum 44:1273-80.

42. Santos LL, Hall p, Metz CN, Bucala R and Morand EF (2001): Role of macrophage migration inhibitory factor (MIF) in murine antigen-induced arthritis: Interaction with glucocorticoids. Clin Exp Immunol., 123:309-14.
43. Selvi E, Tripodi SA, Catenaccio M, Lorenzini S, Chindamo D, Manganelli S, Romagnoli R, Ietta F, Paulesue L, Miracco C, Cintorino $M$ and Marcolongo $R$ (2003): Expression of macrophage migr-ation inhibitory factor in diffuse systemic sclerosis. Ann Rheum. Dis., 62:460-4.

44. Smith SH, Brown MH, Rowe D, Callard RE and Beverly PC (1986): Functional subsets of human helper-inducer cells defined by a new monoclonal antibody, UCHL1. Immunology., 58: 63-70.

45. Steinhoff M, Meinhardt A, Steinhoff A, Gemsa D, Bucala $R$ and Bacher $M$ (1999): Evidence for a role of macrophage migration inhibitory factor in psoriatic skin disease. Br. J. Dermatol., 141: 1061-6.

46. Tan EM, Cohen AS and Fries JF (1982): The 1982 revised criteria for the classification of Systemic Lupus Erythematosus. Arthritis Rheum 25:1271-7.

47. Tang WW, Feng L, Vannice JL and Wilson CB (1994): Interleukin-1 receptor antagonist ameliorates experimental antiglomerular basement membrane antibodyassociated glomerulonephritis. J. Clin Invest., 93:273-9.

48. Tesch GH, Nikolic-Paterson DJ, Metz CN, Mu W, Bacher M, Bucala R, Atkins RC and Lan HY (1998): Rat mesangial cells express macrophage migration inhibitory factor in vitro and in vivo. $\mathrm{J} \mathrm{Am}$ Soc Nephrol., 9: 417-24.

49. Yang N, Nikolic-Paterson DJ, Ng YY, Mu W, Metz C, Bacher M, Meinhardt A, Bucala R, Atkins RC and Lan HY (1998): Reversal of established rat crescentic glomerulonephritis by blockade of macrophage migration inhibitory factor (MIF): Potential role of MIF in regulating glucocorticoid production. Mol. Med., 4: 413-24. 


\section{لمعامل المثبط لإنتقال المكروفاج فى مرض الأنبة الحمراء

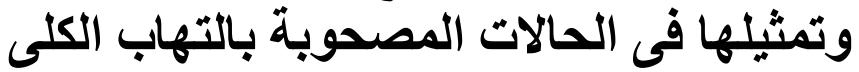

\section{نهلة خطاب1, نهاد النشار 1, نيفين بلرّ2, حنان فهمى2, راجيا فهمى2, نهلة عوض}

1-المركز القومى لبحوث و تكنولوجيا الإشعاع2- كلية الطب, جامعة عين شمس ـالقاهرة-

مصر

تهدف من هذة الدراسة الى التوصل الى الى احتمال تضمن المعامل المثنبط لإنتقال الماكروفاج المباج

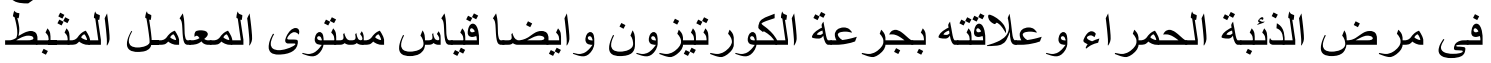

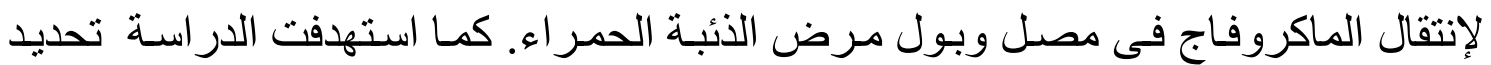
تمثيل المعامل المثبط لإنتقال الماكروفاج الكلوى فى الحالات المصحوبة بالتهاب التهاب الكلى.

\section{طرق البحث}

تم قياس تركيز المعامل المثبط لإنتقال الماكروفاج في المصل و البول بالطريقة الإنزيمية

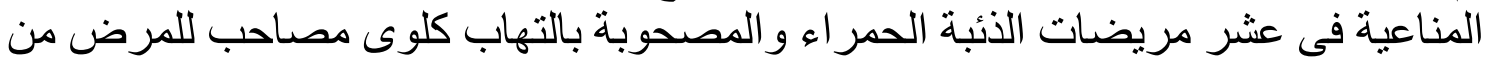

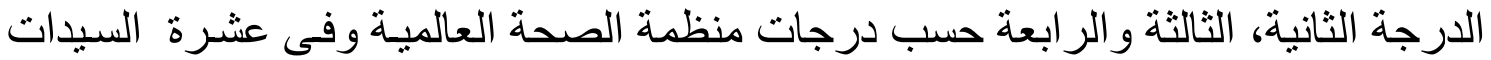

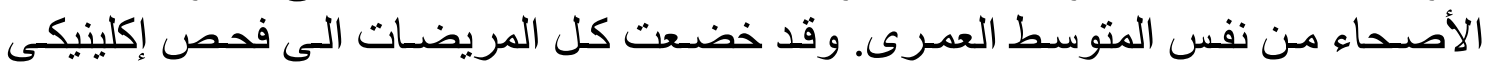

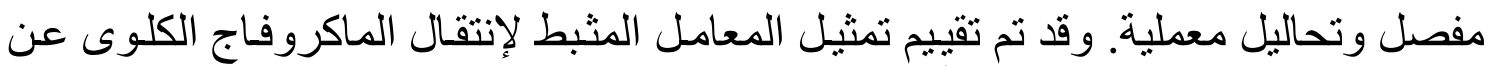
طريق الصبغة المناعية لعينات الأنسجة.

\section{نتائج البحث}

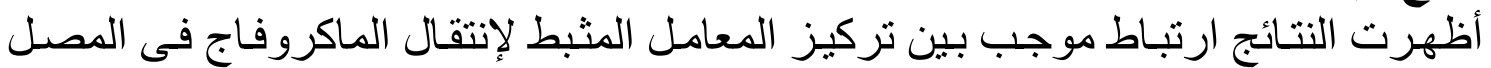

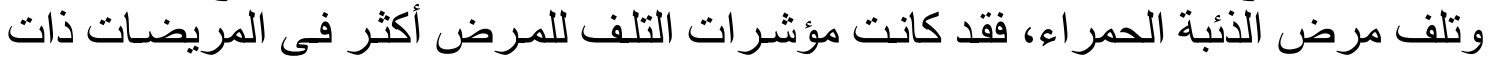

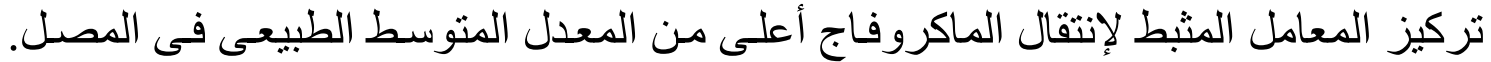

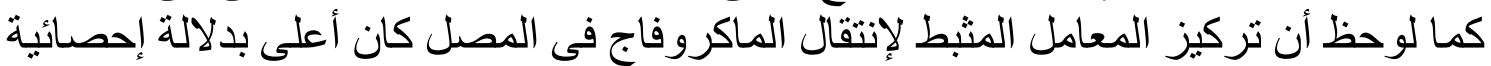

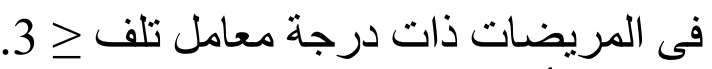

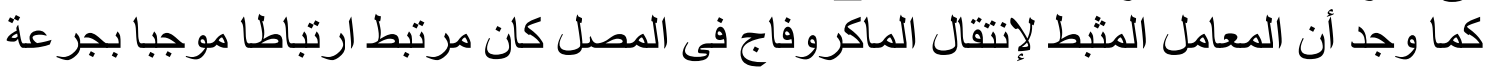

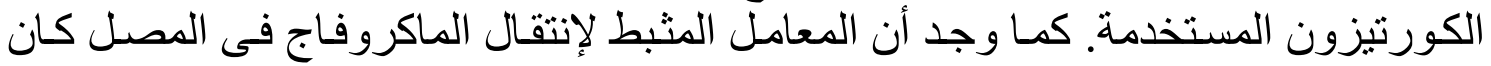

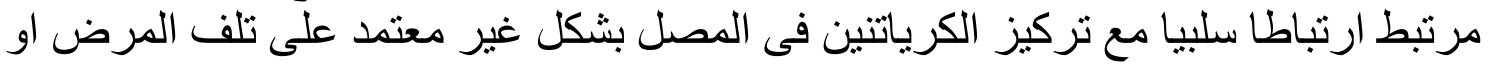
جر عة الكورتيزون.

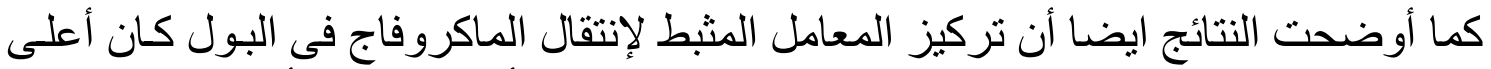

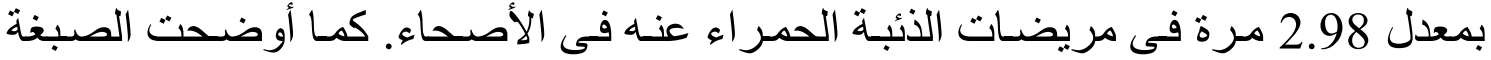

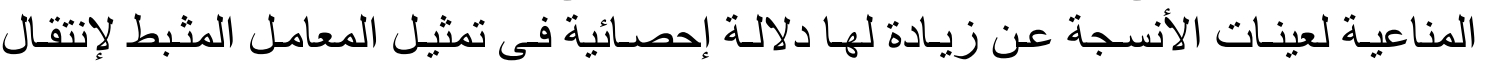


الماكروفـاج في مريضـات الذئبـة الحمـر اء و المصـحوبة بالتهـاب الكلى وكـان هذا التمثيـل

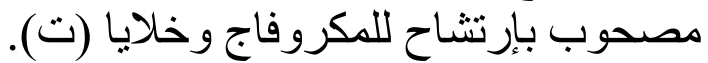

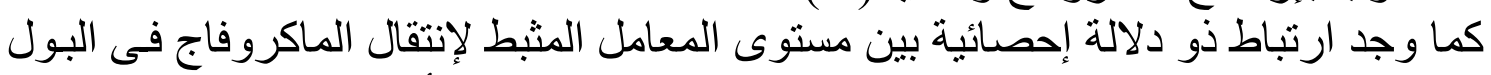

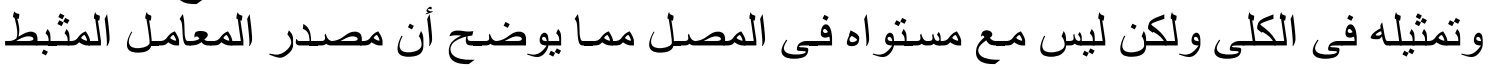

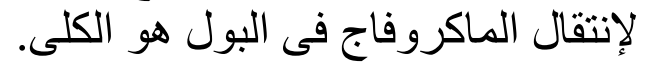

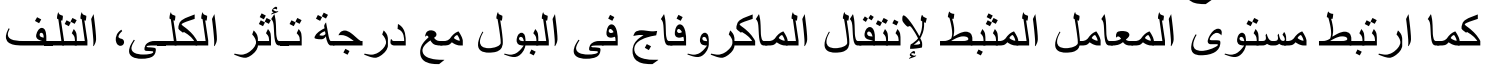

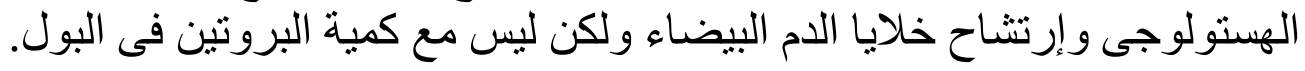

(الإستنتاج

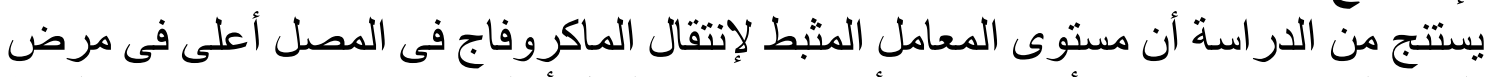

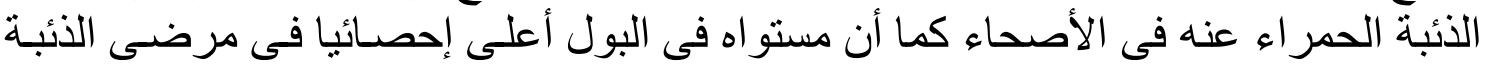

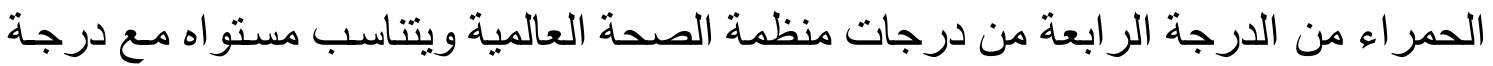

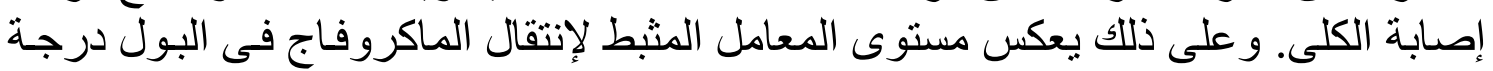

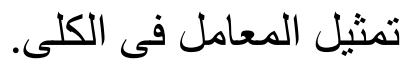

